\title{
Archaeological Assessment of Two Sites in the Vicinity of Floodwater Retarding Structure No. 11, Salado Creek Watershed, Bexar County, Texas
}

David Brown

Paul Lukowski

Thomas R. Hester

Center for Archaeological Research

Jack D. Eaton

Follow this and additional works at: https://scholarworks.sfasu.edu/ita

Part of the American Material Culture Commons, Archaeological Anthropology Commons, Environmental Studies Commons, Other American Studies Commons, Other Arts and Humanities Commons, Other History of Art, Architecture, and Archaeology Commons, and the United States History Commons

Tell us how this article helped you.

This Article is brought to you for free and open access by the Center for Regional Heritage Research at SFA ScholarWorks. It has been accepted for inclusion in Index of Texas Archaeology: Open Access Gray Literature from the Lone Star State by an authorized editor of SFA ScholarWorks. For more information, please contact cdsscholarworks@sfasu.edu. 
Archaeological Assessment of Two Sites in the Vicinity of Floodwater Retarding Structure No. 11, Salado Creek Watershed, Bexar County, Texas

\section{Creative Commons License}

\section{(c) (1) (8)}

This work is licensed under a Creative Commons Attribution-NonCommercial 4.0 International License 


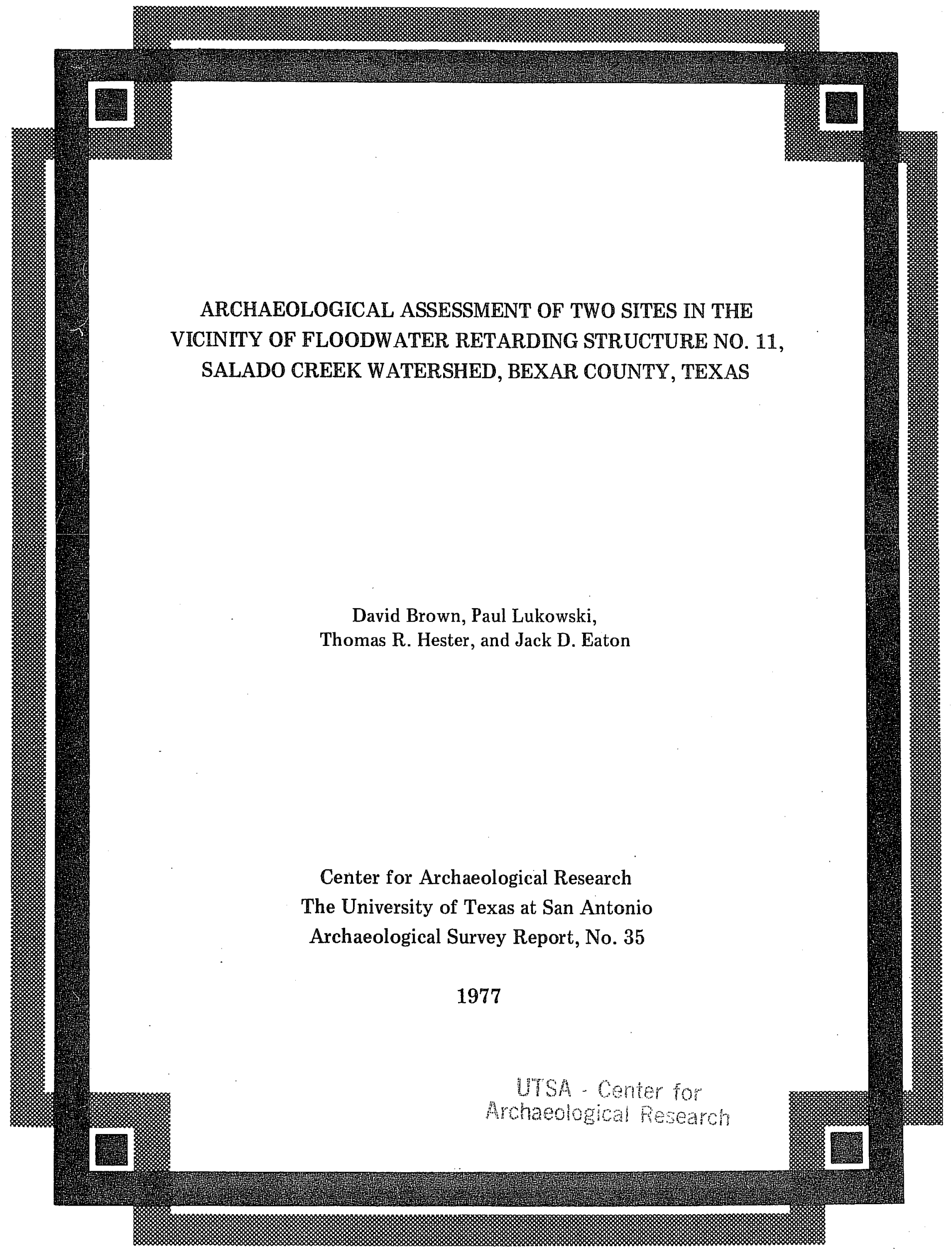




\title{
ARCHAEOLOGICAL ASSESSMENT OF TWO SITES IN THE \\ VICINITY OF FLOODWATER RETARDING STRUCTURE NO. 11, \\ SATADO CREEK WATERSHED, BEXAR COUNTY, TEXAS
}

\begin{abstract}
David Brown, Paul Lukowski,
Thomas R. Hester, and Jack D. Eaton

With an appendix prepared by David Brown

Center for Archaeological Research

The University of Texas at San Antonio

Archaeological Survey Report, No. 35
\end{abstract}

1977 
TABLE OF CONTENTS

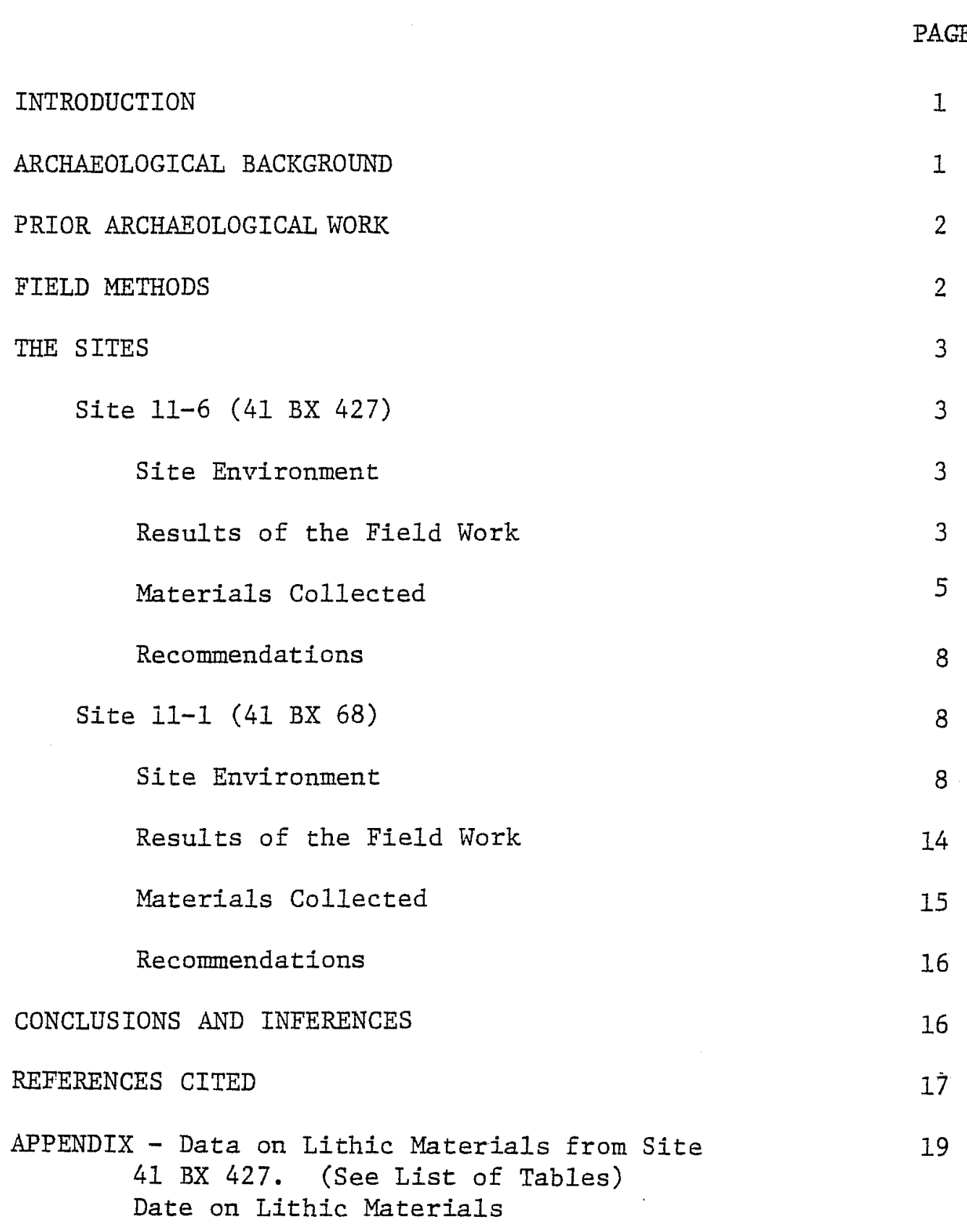




\section{LIST OF FIGURES}

FIGURE

PAGE

1. Site 11-6 (41 BX 427).

2. Site 11-6 (41 BX 427). Lithic artifacts from Southeast Quadrant.

3. Site 11-6 (4I BX 427) and Site 11-I (41 BX 68). Lithic artifacts from Southwest Quadrant.

4. Site 11-6 (41 BX 427). Lithic artifacts from Northeast Quadrant.

5. Site 11-6 (41 BX 427). Lithic artifacts from Northwest Quadrant.

6. Site 11-1 (41 BX 68).

\section{LIST OF TABLES}

TABLE

1. Inter-Quadrant Distribution of Collected Material (By Percentage).

2. Totals of Flakes from Two-Meter Collection Squares.

3. Percentages of Intra-Quadrant Flake Types.

4. Lithic Collection by Quadrant.

5. Intra-Quadrant Distribution of Biface Types (By Percentage).

6. Inter-Quadrant Distribution of Biface Types (By Percentage).

7. Inter-Quadrant Distribution of Bifaces and Utilized Flakes (By Percentage).

8. Intra-Quadrant Distribution of Bifaces and Utilized Flakes (By Percentage).

9. Mean Weights of Lithic Debitage from Two-Meter Collection Squares. 


\section{INTRODUCTION}

In March of 1977, the Center for Archaeological Research at The University of Texas at San Antonio was contacted by Mr. George C. Marks of the United States Department of Agriculture Soil Conservation Service (Temple, Texas) regarding further archaeological research at two archaeological sites within the area of proposed Floodwater Retarding Structure No. 11 on the Salado Creek Watershed in Bexar County, Texas. These two sites had been located in an earlier reconnaissance of the region conducted by the Center for Archaeological Research (Hester et al. 1974). Recommendations made at that time for these two sites included a careful definition of the limits of the archaeological materials and an evaluation of subsurface potential.

Under the general supervision of Dr. Thomas R. Hester, Director of the Center, and Mr. Jack Eaton, Center Research Associate, a field team consisting of Paul Lukowski and David Brown was sent to conduct an intensive survey of the two sites. The survey was designed to evaluate the potential damage to the sites that might be caused by construction of the proposed project. Field work was carried out during April, 1977.

Following the field work, materials collected in the testing program were subjected to cursory analysis in the Archaeology Laboratory, and the present report was prepared. All specimens from these sites are now a part of the permanent collection of the Center for Archaeological Research.

\section{ARCHAEOLOGICAL BACKGROUND}

Prehistoric remains are known to exist all across the northern part of Bexar County. It appears that the Salado Creek watershed was a favored area for aboriginal activities during prehistoric times. Twenty-nine sites were reported in the survey which located the two sites described herein (Hester et al. 1974) and others have been located by subsequent surveys soon to be published (Anne Fox and Thomas C. Kelly, personal commuication).

Based on work in Bexar and surrounding counties, the tentative chronology for the archaeology of the area can be simply stated: 1) the Paleo-Indian period (ca. 9200-6000 B.C.); 2) the Archaic period, often divided into Early, Middle and Late Archaic (ca. 6000 B.C. to A.D. 1000); 3) the Late Prehistoric (ca. A.D. 1000-1600); and 4) the Historic period. Sites from all periods have been reported in Bexar County, but sites from the Archaic, especially the Middle and Late periods, seem to be the most common (Hester et al. 1974).

Typical sites present in the Salado Creek watershed area include burned rock middens, open occupation sites, temporary campsites, chert quarry workshops, and rockshelters. Though examples of each kind of site have been reported, intensive excavation has not yet been undertaken and the relationships of the various sites are not well known. It is hoped that investigations at various sites of each type will eventually help to elucidate the prehistoric occupation of the area. 


\section{PRIOR ARCHAEOLOGICAI WORK}

In 1971, during a survey of the highway right-of-way along FM 1604 , William Fawcett recorded a quarry-workshop site (later designated 41 -BX 68) on the north side of the highway between EIm Creek and Bulverde Road. As the full extent of the site remained unknown no further work was recommended at that time. During the 1974 survey of Floodwater Retarding Structure No. 11, conducted by Feris A. Bass and other personnel from the Center for Archaeological Research (Hester et al. 1974), the site was re-examined and five other sites were recorded within the proposed project area. Two of these recommended sites were for further investigation before construction was to begin: 11-1 (41 BX 68), the quarry-workshop site, and 1I-6 (41 BX 427), an open campsite.

Small surface collections were made at both sites during the original survey, and these have been included with the current materials in assessing the archaeological potential of the sites.

\section{FIELD METHODS}

Initial evaluation of each site began with a careful inspection of exposed surface materials. This surface survey located and marked the horizontal extent of each site and defined central lithic concentrations within the boundaries of site 11-1. Upon completion of the surface inspection, five shovel tests were placed at each site. The location of each shovel test was calculated to provide information on the nature and depth of subsurface cultural materials over a broad area of the site.

All shovel tests at site 11-1, a potentially important site, were screened through 1/4-inch wire mesh for recovery of culturally related materials. Because of the lack of time and the hardness of the clay soils, the shovel tests at 11-6 were not screened, but excavated soil was carefully inspected by hand.

After surveying and testing, a contour map was prepared for each site. Each map shows the site boundaries as determined by the preliminary reconnaissance and indicates the location of each shovel test. In addition, identifiable landmarks and the general topography of the surrounding area was included to facilitate relocation in case of any further work.

At site 11-6, a controlled surface collection was made so that a broad range of materials could be salvaged before eventual inundation in the sediment pool of the dam. All surface materials from four two-meter squares were collected, and all culturally relevant specimens in each unit was brought back to the lab for further analysis. The surface of the remainder of the site was divided into four quadrants and all visible utilized or worked chert artifacts were collected. 
THE SITES

Site $11-6(41 B \times 427)$

Site Environment

Site 11-6 (41 BX 427) lies on a low terrace above and to the north of the confluence of the East and West Elm Creeks. The creeks themselves were dry at the time of the field investigations, and it is possible that they contain water only during heavy rainstorms. On the south side of the creek, the bank is steep and rocky, in some places forming a sheer rock bluff several meters high. On the north bank, where the site is located, there is almost no place which can be pointed to as the edge of the creek bed except where the bedrock of the creek bed begins to be covered by small amounts of soil and vegetation among the rocks. The stream terrace gradually slopes upward to the north, so that the northern boundary of cultural materials is some five to six meters above the creek bed (Fig. 1).

The site is noticeable in several small clearings which are separated by fairly dense brush and wooded areas consisting mainly of live oak and juniper, with some mesquite and cacti. Thick, short stem grass covers the clearings. Near the edge of the creek, and even in what appears to be part of the creek bed, vegetation is especially dense, suggesting again that the creek does not flow often in modern times.

Soils at the site are listed by the Soil Survey of Bexar County as being Crawford and Bexar Stony Soils, which vary from a dark grayish-brown to a reddish-brown clay and have a depth ranging from $43 \mathrm{~cm}$ to $115 \mathrm{~cm}$ above limestone bedrock. Our investigations suggest that the predominant type is Crawford, described as a dark stony clay in the top eight or nine inches with 10 to 40 percent of the layer consisting of chert and limestone fragments (Taylor et al. 1966). The subsoil is $15 \mathrm{~cm}$ to $35 \mathrm{~cm}$ of cherty clay covering a hard Iimestone.

Parts of the site have been disturbed by recent activities. A road enters the central clearing of the site from the east. A small barbed wire enclosure, possibly a deer feeder, sits in a clump of trees at the eastern edge of the clearing, and in the south central part of the clearing are traces of a deer blind. Survey lines and markers are present to the west of the site, extending out from the power line right-of-way. There are several areas obviously cleared by bulldozers. In a large clearing to the north of the central clearing, a 10- by 20-meter trough-like pit has been scooped out to a depth of more than a meter. There are also various core drillings visible near the site.

Results of the Field Work

Preliminary investigation at 11-6 indicates that it is a light lithic scatter on the primary terrace of West EIm Creek. Surface materials extend more than 100 meters north from the bank of the West Elm Creek, and from 20 meters west of East Elm to 80 meters east of where West Elm turns north, a distance of some 200 meters. 
This page has been

redacted because it

contains restricted

information. 
Shovel tests at the site produced no conclusive evidence of any significant subsurface deposit. Only a few small flakes were encountered in the top few centimeters of soil. Observations of soil profiles in each test and at the bulldozer cut in the northeastern part of the site indicated an average soil depth of 50 centimeters, but there was no indication that the cultural material extended to this depth.

Materials Collected

Shovel Tests

Only two of the five shovel tests at 11-6 produced any cultural materials. Test 非 contained one secondary flake (i.e., a piece struck from a chert nodule which has had the cortex partially removed), one possible utilized flake, and three small chert chunks possibly related to some step in the flintknapping process. Shovel test $\$ 2$ contained an interior flake (i.e., one struck from a chert nodule from which the cortex has been completely removed) and one other possible utilized flake.

Surface Collection

The surface collection at $4 I$ BX 427 was designed to recover a large sample of utilized lithic material maintaining as much control of areal provenience as possible in the time allotted. As noted earlier in the text, the site was gridded into four sections oriented on magnetic north with the aid of a Brunton compass (Fig. 1). The location of the central point for the quadrant grid was chosen to be approximately in the center of the clearing which appeared to contain the heaviest concentration of lithics. Examination of the site boundaries, however, shows that the quadrants are of unequal size (Fig. 1). In addition, the northeast quadrant seemed to have a greater density of lithic materials than the others.

The collection consisted of lithics from the surface of each quadrant which showed signs of being worked or of having an amount of edge damage which might suggest utilization. In order to determine the relative percentage of worked and utilized material to the total lithic sample present on the surface, a 2-meter square was staked off in each of the quadrants and all culturally-related debris was collected. These smaller collection squares were located in areas which appeared to contain enough material to insure adequate sample size; for this reason, lithic material in any collection square is not necessarily an accurate reflection of the density of surface lithics in any given quadrant. These inter-quadrant percentages are included in Table 1 (see the Appendix*) because they show a strong correspondence to the inter-quadrant distribution of materials from the general collection. This table seems to suggest that the focus of activity at the site was in the northeast quadrant.

*Tables 1-9 detailing the lithic data from 41 BX 427 are all found in the Appendix. 
Comparisons of percentage categories of lithics within each of the two-meter collection squares should be reasonably accurate since in choosing any square there was no conscious bias toward the type of cultural material included. Simple tabulation of lithics from these squares is shown in Table 2. Table 3 shows the percentage of flake types as they relate to the lithic reduction process. Note the high percentage of secondary flakes in the southwest quadrant and the high percentage of cortex flakes in the southeast quadrant. Table 4 shows the percentages of flakes in each square which have a pattern of edge damage suggestive of utilization; note that the smallest percentage of utilized flakes occurs in the quadrant with the greatest concentration of total material.

Table 5 shows the artifactural material collected from the four quadrants; a total of 411 possible utilized and worked stone artifacts were collected but 110 flakes were not included in this sample because they had insufficient edge damage to enable us to confidently categorize them as "utilized." An additional 38 utilized flakes collected from the two-meter squares were added to this sample to make a total of 339 artifacts available for analysis. Table 6 compares the inter-quadrant relative percentages of biface types. Note the relatively high percentage of thick bifaces in this table and in Table 7 which is the inter-quadrant distribution of biface types. The high percentages of thick bifaces; of cortex flakes, and the larger number of cores (Table 5) present in the southeast quadrant suggest that this area might have been used for the initial reduction of tools, perhaps made from cobbles out of the bed of the West Elm Creek. The possibility that this distribution of heavier material lower down the hill slope is related to some type of downslope movement is not supported by the relatively high percentage of thin bifaces and low percentage of thick bifaces present in the southwest quadrant which is also on the lowest part of the terrace near the creek.

Table 8 shows the intra-quadrant percentage distribution of bifaces and utilized flakes. Note that the eight cores and the four retouched flakes collected are not included in this table. Table 9 shows the mean weights of all utilized flakes collected. The non-utilized flakes are lighter on the average than the utilized ones from both the collection squares and the general collection. The discrepancy in the mean weights of utilized flakes between the quadrants and the collection squares is almost certainly due to sampling error as there would be a bias toward larger clearly visible pieces of chert in the general collection. The difference in weights between utilized and non-utilized flakes, on the other hand, is probably not due to sampling error, but due rather to the fact that the flakes chosen for a specific task are more likely to be those which are larger and easier to manipulate.

No detailed analysis has been undertaken of the use wear patterns on the lithics collected from the site. Without this analysis it is difficult to ascertain the functions of the tools collected and consequently difficult to speculate about the activities of the prehistoric occupants of the site. However, a few general observations made during the cataloging of the material can be added here. 
The majority of the flakes show unifacial wear, that is, wear on only one side of the cutting edge, indicating that the edge was used primarily in one direction at right angles to the material being worked, as in a scraping motion. In addition, many of the flakes show moderately heavy wear, with parts of the original cutting edge snapped off, suggesting that the tools were utilized in scraping some relatively hard substance such as wood or leather rather than plant materials and then discarded after edge breakage made them inefficient or unserviceable. This does not indicate a predominance of this kind of activity because the surface collection was biased toward pieces with obvious or moderately heavy wear.

Various edges of the flakes were used in cutting; no particular edge stands out as predominant. Sometimes more than one edge was used but more often only one edge has enough wear to suggest repeated utilization. Several specialized flake tools such as burins, gravers and utilized blades are present though not in any numbers. No attempt was made to separate and count them due to time limitations. In addition to the flakes, a few cores, or chert nodules from which previous flakes had been removed, showed signs of utilization, probably as a crude kind of chopper. (The large flake mentioned in Table 10 may also have been used as a chopper.) These chopper-like artifacts are relatively rare, however, suggesting that heavy woodworking industries and other heavy work which would require a chopping tool were not comon at the site.

Bifaces are numerous at the site (see below), perhaps suggesting that the camp was at least partially used for hunting. Most of the bifaces are either obviously projectile points, or thin bifaces whose shape suggests that they either functioned as projectile points or were eventually intended to be such. Some of these thin bifaces were probably intended as knives and others may have functioned as such when they, during the preform stage, were revived as a result of hinging and flaws. Though a number of thick bifaces are present (more than 1.5 centimeters thick), it should be noted that generally these are only slightly larger than 1.5 centimeters. The paucity of larger quarry blanks and the relatively few cores suggest that much of the quarrying and initial reduction activities were carried out elsewhere, probably at the nearby 41 BX 68 .

In addition to the materials described above, the surface collection yielded a number of whole or fragmentary projectile points and several thin bifaces which may have been point preforms or knives. With reference to the quadrant method used in the collection, these artifacts were distributed as follows:

Southeast Quadrant (Ffg. 2)

Bulverde ( 1 ; stem fragment)

Pedernales (1; unfinished?)

probable knife (edges resharpened and stained; concave base; cf. Aveleyra Arroyo de Anda et al. 1956 for examples of similar specimens from Coahuila, Mexico)

preforms and preform fragments 
Southwest Quadrant (Fig. 3)

"Early Corner Notched" (1; patinated; cf. Hester 1971)

Biface mid-section ( 1 )

Northeast Quadrant (Fig. 4)

Pedernales (2)

Lange (1)

Montell (1)

stemed dart point fragments (2)

unfinished stemmed dart point (1)

large lanceolate preform (1)

preform fragments

Northwest Quadrant (Fig. 5)

Montell (1)

Travis-1ike (I)

corner-notched dart point (1; cf. "Early Comer Notched" form)

Guadalupe tool (Hester and Kohnitz 1975)

preform fragments

The greatest density of lithics occurred in the northwest and southeast quadrants. However, most of the diagnostic projectile points and tools came from near the central part of the collecting area where the four quadrants meet (see Fig. 1).

\section{Recommendations}

Evaluation of site 11-6 indicated a thin subsurface occurrence of cultural materials linked to Pre-Archaic and Early, Middle and Late Archaic occupations (perhaps a temporary hunting camp, with a variety of campsite tasks being carried out). In view of the shallow depth of soil above bedrock, the stony character of the soils, and the sparse nature of this cultural residue, further subsurface testing appears unnecessary. Because of the amount of lithic debris on the surface, and the impending destruction of the site because of its location in the sediment pool, the authors conducted an intensive controlled surface collection of materials. The collected materials have been only briefly noted here, and are stored at the Center for Archaeological Research, awaiting intensive study in the future.

\section{Site 11-1 (41 BX 68)}

\section{Site Environment}

This site lies on the top of a large flat ridge, high above the east bank of Elm Creek. On the north side there is a long cleared terrace that slopes down to East Elm Creek. The north edge of the site is encircled by Elm Creek and this long terrace, but to the south along Elm Creek (below the confluence of the two branches) the terrace disappears into a steep rocky bluff (Fig. 6). 


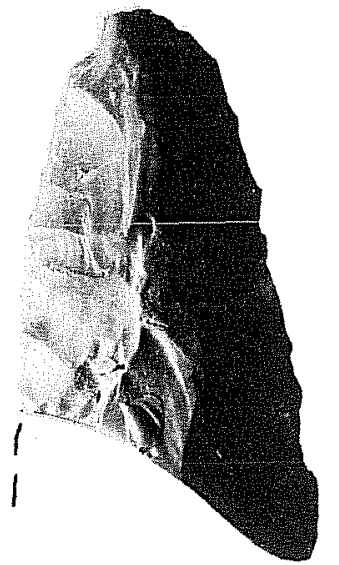

a

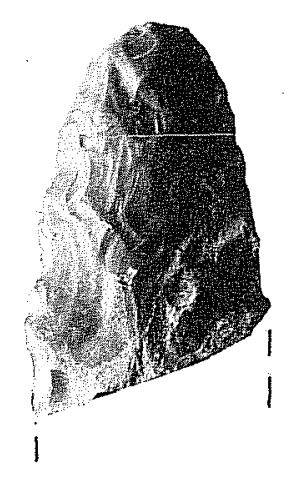

b

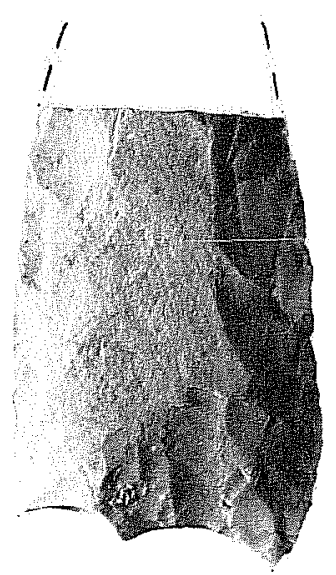

c

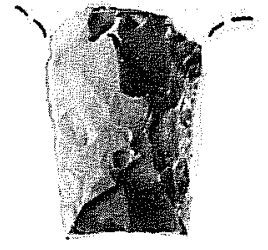

d

$$
\left.\left.\left.\left.\left.\left.\mathrm{cm}^{\prime}\right|_{1}\right|^{\prime}\right|^{\prime}\right|^{\prime} 3\right|^{\prime} 4\right|^{\prime} 5 \mid
$$

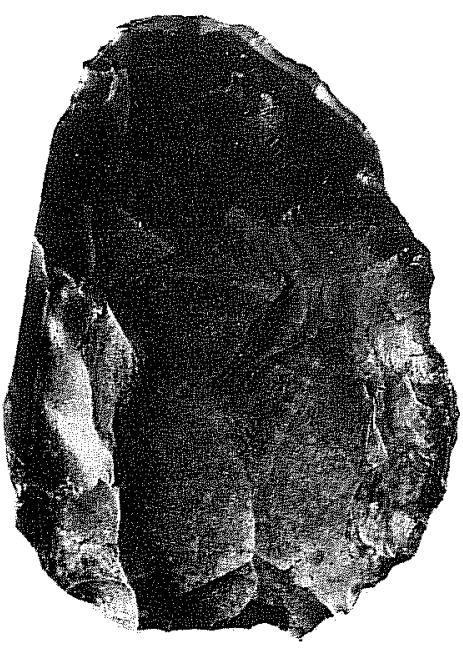

e

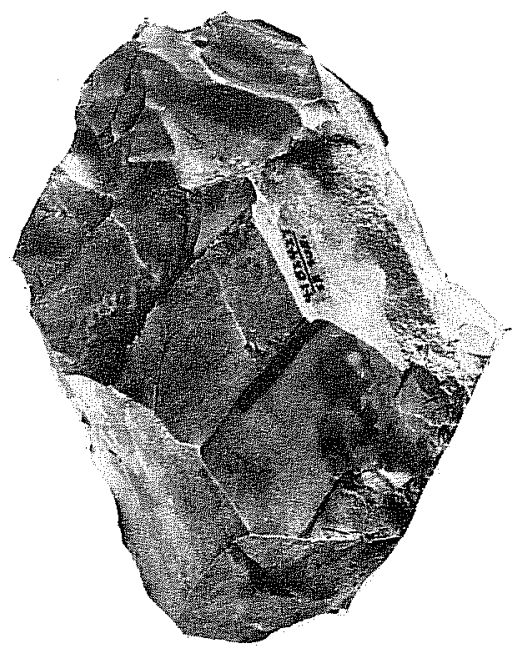

f

$\mathrm{cml} / 1 / 2 /\left.\left.3\right|^{\prime} 4\right|^{1} 5$

Figure 2. Site 11-6 (4) BX 427). Lithic artifacts from Southeast Quadrant. a,b, preform fragments; $c$, probable knife; d, Bulverde stem fragment; $e-f$, preform fragments. 


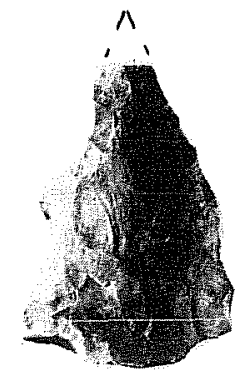

a

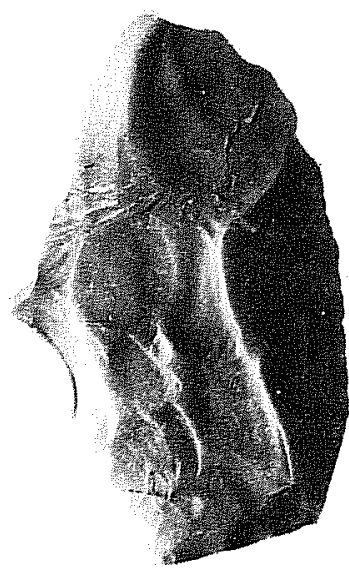

c

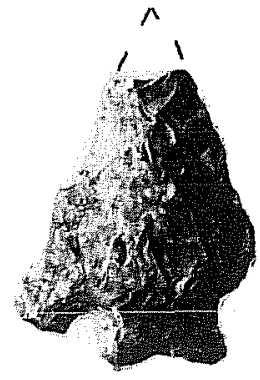

b

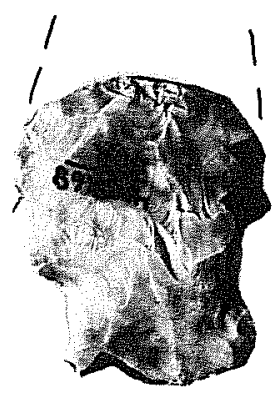

d

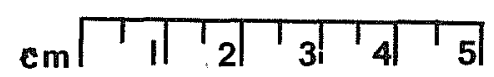

Figure 3. Site 11-6 (41 BX 427) and Site 11-1 (41 BX 68). Lithic artifacts from Southwest Quadrant. From site 11-6: a, biface mid-section; b, corner notched point. Surface lithics from site 11-1: c, biface, trimmed along right edge; $d$, stemmed dart point fragment. 


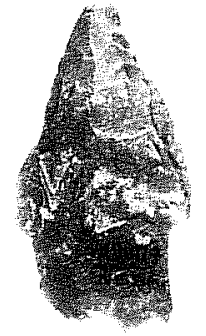

a

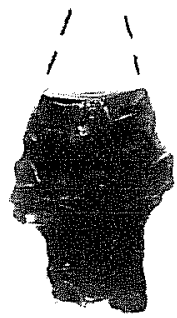

b

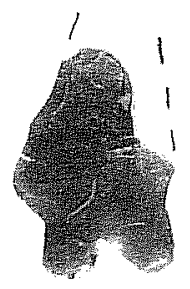

c

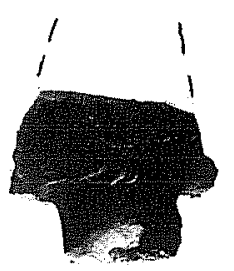

d

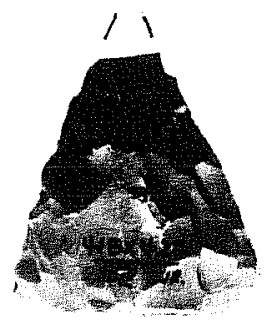

e

$$
\left.\left.\left.\mathrm{cm}\left|{ }^{\prime} 1\right|^{\prime} 2\right|^{\prime} 3\right|^{\prime} 4\right|^{\prime} 5 \mid
$$

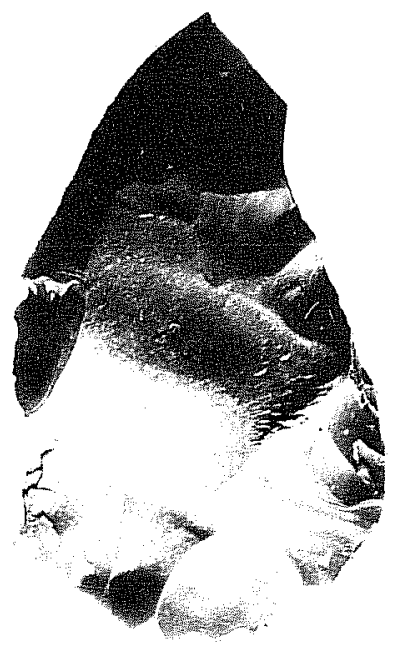

f

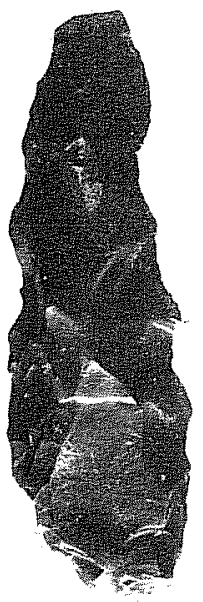

g

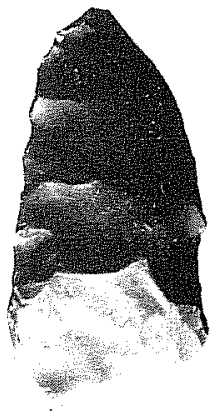

h

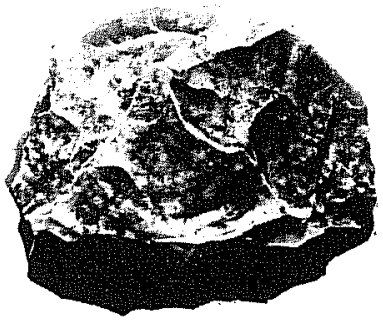

i

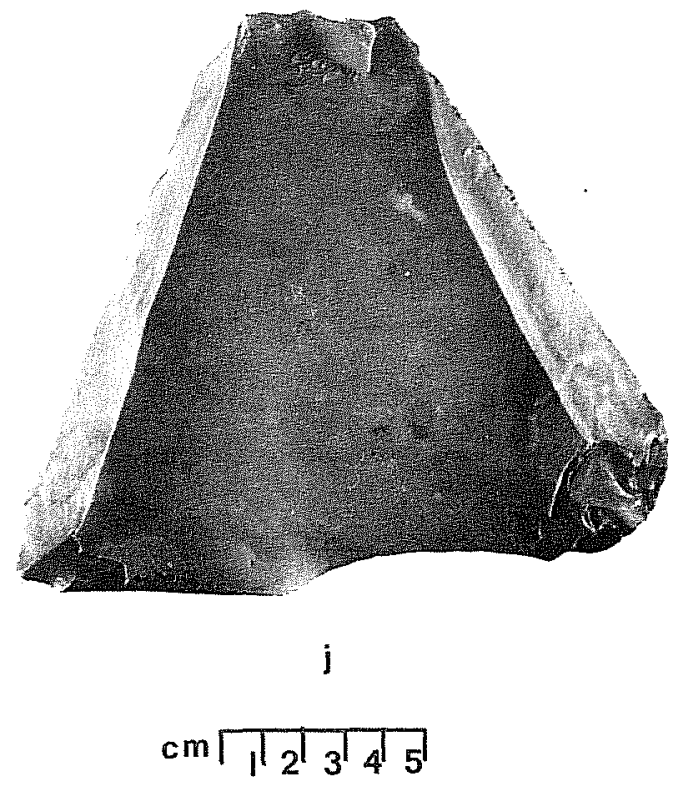

Figure 4. Site 11-6 (41 BX 427). Lithic artifacts from Northeast Quadrant. a,b, Pedernales point; c, Montell point; d, Lange point; e, preform fragment; $f$, quarry blank; $g, h$, preforms; $i$, oval biface; $j$, interior flake. 


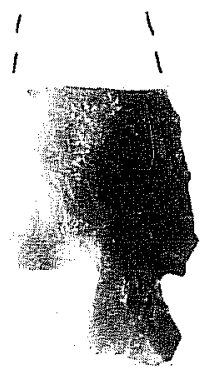

a

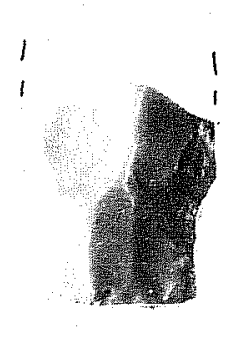

b

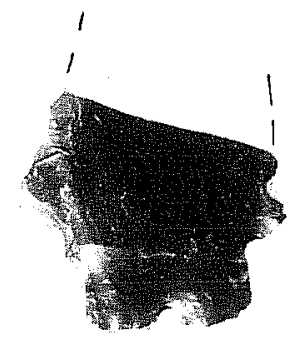

C

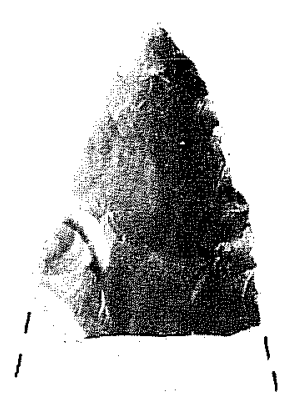

d

$$
\left.\left.\left.\mathrm{cm}\left|{ }^{\prime} 1\right|^{\prime} 2\right|^{\prime} 3\right|^{\prime} 4\right|^{\prime}{ }^{5} \mid
$$
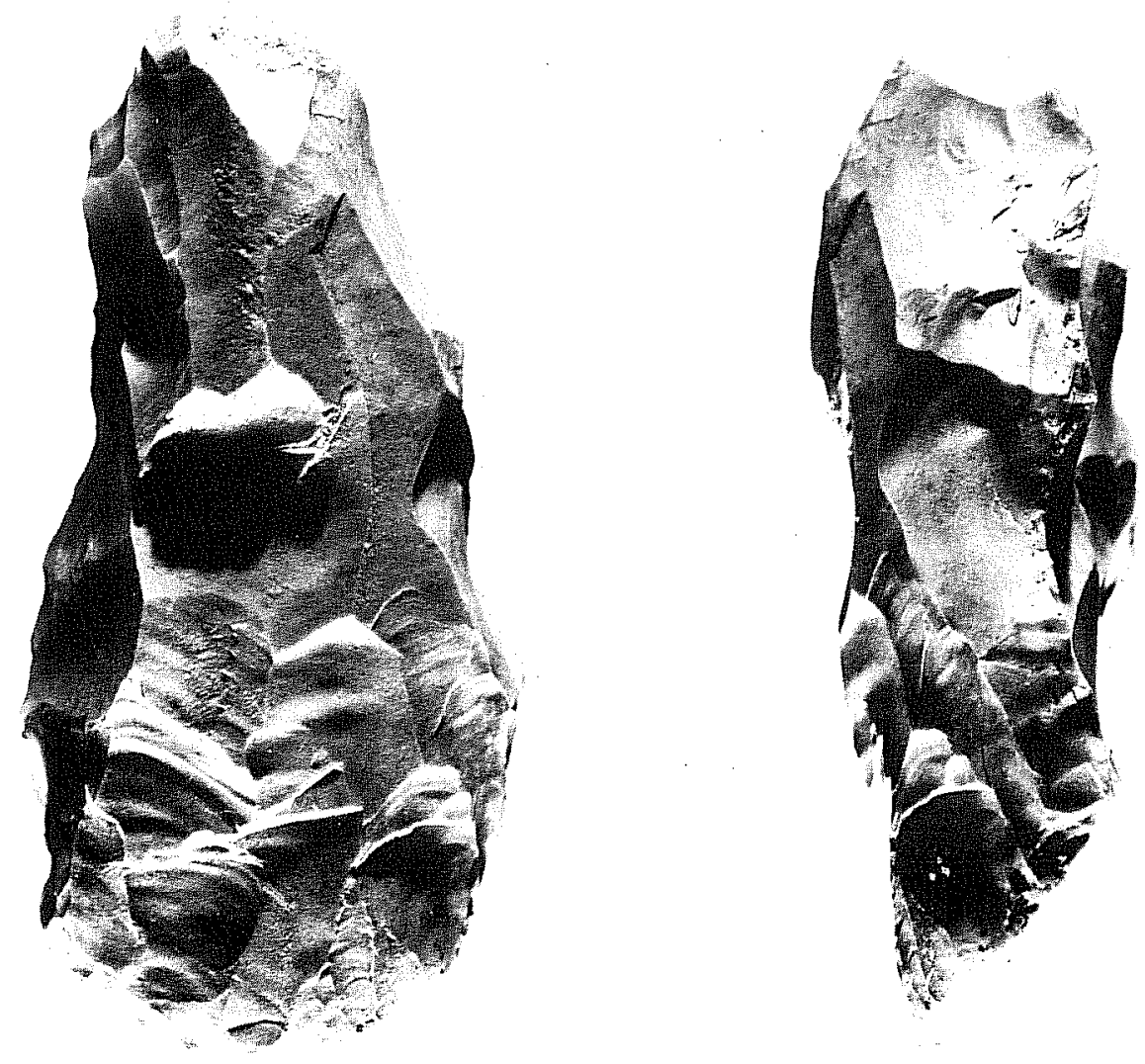

\section{$\left.\left.\left.\mathrm{cm}\left|{ }^{\prime}{ }_{1}\right|_{2}\right|^{\prime}{ }^{\prime} 3\right|^{\prime} 4\right|^{\prime} 5 \mid$}

Figure 5. Site 11-6 (41 BX 427). Lithic artifacts from Northwest quadrant. $a$, corner notched point fragment; $b$, Thavis-11ke point fragment; $c$, Montell polnt basal fragment; d, distal tip, preform fragment; e, Guadalupe tool (top view) bit end down; $f$, same tool (side view). 
This page has been

redacted because it

contains restricted

information. 
Vegetation at the site is very similar to that of 11-6. Live oak and juniper are predominant, with mesquite present in greater numbers than at site 11-6; some wild persimmon and small acacia also occur around the site. In the clearings are short grasses, wildflowers, agarita, briar, spanish dagger, and a variety of cacti.

The soil type is also similar to that of 11-6: shallow, stony clay of the Crawford series. The major difference is the presence of numerous chert cobbles and angular chert fragments on the surface and in the soil. Minor variations occur in the color, clay content and depth of the soil across the site. There is little soil depth on the ridge top and it is possible that in some areas erosion has further reduced a soil profile which was shallow to begin with.

Recent human activity at the site has already caused considerable damage and dislocation to surface material. A power line right-of-way cuts through one of the heaviest concentrations of lithics at the site. Some material, heavily patinated from long exposure, shows signs of recent breakage, possible from heavy construction equipment. Artifactual materials show no signs of having been seriously affected by cattle grazing at the site, but local relic collectors may have scoured the site for Indian artifacts. Thomas $\mathrm{C}$. Kelly of the Center staff has visited the site several times over the past three years and suggests that some of the quarry-workshop materials (e.g., blanks and preforms) present on the surface at the time of the Center's 1974 survey (Hester et al. 1974) have now disappeared.

Results of the Field Work

Surface survey of 11-1 indicated that the site was utilized as a quarry and chipping station. A high incidence of retouched and utilized flakes additionally suggests that other kinds of activities may have been carried out at the site (cf. Kelly and Hester $1975 \mathrm{~b}$ for a discussion of a similar artifact assemblage at $41 \mathrm{CM} 89$ ). Lithic materials are widely scattered over the entire ridge-top area, trailing off as the ridge begins to slope toward the creek. Several heavy concentrations of quarry materials were encountered within this area of light scatter.

Surface lithic materials begins at the junction of FM 1604 and the CPS transmission lines, and continues northwest along the power line right-of-way for 550 meters. From this northernmost point of 11-1, materials can be observed expanding out across the sloping terraces to the east and west. Along FM 1604 more lithic material occurs east from Elm Creek for a distance of approximately 750 meters. Indications are that lithic material can be expected to continue to the south of FM 1604.

Within the boundaries of the site a central concentration of cores and debitage measuring 200 by 150 meters was located in the power line right-ofway beginning 120 meters north of FM 1604. Southwest of this central concentration, and adjacent to it, is another concentration which extends east 400 meters from EIm Creek, along the fence Iine which parallels FM 1604. At the easternmost end of this concentration, where it joins the central area concentration, it extends 120 meters north of the fence line. At the western end above Elm Creek it narrows to fifty meters in width. 
Shovel testing at site 11-1 was confined to the ridge-top area, in the zone of the heaviest concentration of surface lithics. Artifactual materials were recovered from each of the five test units dug, and in each unit the collected materials were generally confined to the upper $10 \mathrm{~cm}$. By comparison to site 11-6, there seemed to be even less soil above the limestone bedrock; the deepest test went only $35 \mathrm{~cm}$, while the others encountered solid limestone at $20 \mathrm{~cm}$.

\section{Materials Collected}

Al1 shovel tests within site 11-1 led to the recovery of cultural materials. The amounts from any given shovel test do not indicate a large deposit of buried artifacts, with the possible exception of shovel test 5 which yielded a total of 60 flakes within the top $20 \mathrm{~cm}$. A tabulation of materials from all shovel tests is included below:

\begin{tabular}{|c|c|c|c|c|c|}
\hline $\begin{array}{l}\text { Lithic } \\
\text { Debris } \\
\text { Categories }\end{array}$ & $\begin{array}{l}\text { Shovel } \\
\text { Test } 1\end{array}$ & $\begin{array}{l}\text { Shovel } \\
\text { Test } 2\end{array}$ & $\begin{array}{l}\text { ShoveI } \\
\text { Test } 3\end{array}$ & $\begin{array}{l}\text { Shovel } \\
\text { Test } 4\end{array}$ & $\begin{array}{l}\text { Shovel } \\
\text { Test } 5\end{array}$ \\
\hline $\begin{array}{l}\text { Primary } \\
\text { Flakes }\end{array}$ & $\perp$ & -- & -- & - & 3 \\
\hline $\begin{array}{l}\text { Secondary } \\
\text { Flakes }\end{array}$ & 8 & 5 & 2 & 8 & 22 \\
\hline $\begin{array}{l}\text { Interior } \\
\text { Flakes }\end{array}$ & 4 & 1 & -- & 4 & 20 \\
\hline $\begin{array}{l}\text { Retouched } \\
\text { Flakes }\end{array}$ & - & - & -- & -- & 8 \\
\hline $\begin{array}{l}\text { Utilized } \\
\text { Flakes }\end{array}$ & 4 & 2 & 1 & 2 & 7 \\
\hline Cores & - & 1 & - & 3 & 2 \\
\hline $\begin{array}{l}\text { Chunks/ } \\
\text { Waste }\end{array}$ & 2 & 32 & -- & 7 & 14 \\
\hline $\begin{array}{l}\text { Core } \\
\text { Remnants }\end{array}$ & -- & - & - & -- & 1 \\
\hline
\end{tabular}


Shovel test 3, with the least amount of Iithic material, was located outside of the area of heaviest concentration on a terrace where we suspected that buried deposits might occur. Shovel tests 1 and 4, which produced approximately similar percentages of materials, were both located in the power line right-of-way, near areas of heavy surface concentrations. The most productive test of all, number 5, was located in the area of heavy surface concentration along the fence line, between the power Iine and Elm Creek.

During the testing phase two bifaces were collected. One is retouched along one long side, possibly for use as a scraper, and the other is a basal fragment from an expanding stem, convex base Archaic dart point (Fig. 3). This point is too badly damaged to allow classification. In addition, a collection was made during the original survey of the site (see Hester et al. 1974). Materials recovered at that time included large chopper-like artifacts (many of these are cores), knives, side and end scrapers, three bifaces with edge damage, and a burin.

Recommendations

Initial testing at $11-1$ (41 BX 68) indicates a large quarry/workshop area extending over many acres. Shovel tests placed at the site do not indicate any great depth of cultural materials. Portions of the site have been badly damaged by the power line right-of-way. Though quarries have been studied in surrounding areas and have been located in recent surveys of northern Bexar County (as at 41 BX 301), no intensive study has yet been undertaken. The fact that many flakes lie in situ on the surface in association with the cores from which they have been struck (a circumstance noted by the authors of this report and other archaeologists who have visited the site) suggests that this site may be useful in such a study.

Since the dam could possibly cut into part of the central concentration of materials at the site, and with the construction activities in surrounding areas threatening the entire site, the authors recommend an intensive controlled surface collection of materials from the site. This should be accompanied by further subsurface testing in the southwest part of the site along the fence line.

\section{CONCLUSIONS AND INFERENCES}

The surface inspection of 11-6 noted a relatively higher percentage of worked stone and smaller flakes than large flakes and cores. This would suggest that the site was a campsite rather than an area whose primary function was the manufacture of tools, such as a quarry site or chipping station. Some natural chert cobbles occur at the site, but in comparison to the enormous numbers present at 11-1 (only a kilometer away), they are rare. Some tools were initially made here, but most commonly they were probably resharpened or reduced to final form from a quarry blank produced at $11-1$.

The density of tools on the surface also suggests that the site was not a long-term occupation, but rather an area for short-term camping or some 
specific, but brief, activity (perhaps related to hunting). Of the projectile points and point fragments collected at the site, several have been placed in typological categories, giving a rough idea of the period of occupation at the site. These points include Pedernales, Bulverde, Travis, "Early Corner Notched," and Montell, which indicate sporadic occupation during PreArchaic and Early, Middle and Late Archaic times, perhaps spanning the time period from ca. 5500 B.C. to the early centuries A.D. The hypothesized "phases" of Weir (1976) possibly represented at this site include San Geronimo, Clear Fork, Round Rock and San Marcos.

Though the construction of the power line at site 11-1 has left a quantity of fractured chert on the surface, there is little doubt that this area is the center of an important quarry workshop where natural chert cobbles were initially tested and reduced into transportable sizes. The ground surface for many acres around this power line area is strewn with chert cobbles, a number of them "tested" by the aboriginal flintknapper for the quality of chert; this was done by removal of one or two small flakes. Indications are that in several parts of the site a large amount of material is available for the study of prehistoric stone-working technology.

The only temporal indicator found at $11-1$ is a damaged dart point base belonging to the Archaic period. Although collectors may have removed some of the diagnostic evidence at the site, a careful surface collection might turn up enough datable projectile points to provide a better estimate of the use span of this large site.

Quarry sites have been located in Bexar and surrounding counties, and some have been subjected to preliminary analysis (Kelly and Hester 1975a, Kelly and Hester 1975b, Patterson 1974, and Briggs 1971). Only one site has been intensively analyzed ( $P$. Katz, ms. in preparation on site 41 BX 301 ) and no major excavations have been carried out. The latter is the result of the fact that quarry sites are usually located in areas with rock outcropping near the surface and the shallow soils make excavation impractical. Surface collections have been made in some of the sites reported above. Further collection at $11-1$ is necessary if it is to be destroyed during the construction of Floodwater Retarding Structure No. 11.

\section{REFERENCES CITED}

Aveleyra Arroyo de Anda, L., M. Maldonado-Koerdell and P. Martinez del Rio

1956 Cueva de la Candelaria. Memorias del Instituto Nacional e Historia V. Mexico.

Briggs, A. K.

1971 An Archeological Survey of Ingram Reservoir. Texas Historical Survey Committee and Texas Water Development Board. Archeological Survey Report 9.

Hester, T. R.

1971 Archeological Investigations at the La Jita Site, Uvalde County, Texas. Bulletin of the Texas Archeological Society 42:51-148. 
Hester, T. R., with the collaboration of F. A. Bass, Jr., A. A. Fox, T. C. Kelly, M. F. Chadderdon and E. S. Harris, with an appendix by T. C. Kelly

1974 Archaeological Survey of Areas Proposed for Modification in the Salado Creek Watershed, Bexar County, Texas. Center for Archaeological Research. The University of Texas at San Antonio, Archaeological Survey Report 3.

Hester, T. R. and H. Kohnitz

1975 Chronological Placement of "Guadalupe" Tools. La Tierra $2(2): 22-25$.

Kelly, Thomas C. and T. R. Hester

1975a Additional Archaeological Survey in the Dry Comal Watershed, Comal County, South Central Texas. Center for Archaeological Research, The University of Texas at San Antonio, Archaeological Survey Report 10.

1975b Archaeological Investigations at Four Sites in the Dry Comal Watershed, Comal County, South Central Texas. Center for Archaeological Research, The University of Texas at San Antonio, Archaeological Survey Report 15.

Patterson, P. E.

1974 Upper San Marcos River Watershed, Hays County, Texas: An Archeological Survey of Areas Proposed for Modification. Texas Archeological Survey, The University of Texas at Austin, Research Report 42.

Taylor, F. B., R. B. Hailey and D. L. Richmond

1966 Soil Survey of Bexar County, Texas. United States Department of Agriculture Soil Conservation Service in cooperation with Texas Agricultural Experiment Station.

Weir, Frank A.

1976 The Central Texas Archaic. Unpublished Ph.D. dissertation. Washington State University. 
APPENDIX

Data on Lithic Materials from Site 41 BX 427

Prepared by David Brown 
TABLE 1

INTER-QUADRANT DISTRIBUTION OF COLLECTED MATERIAL (BY PERCENTAGE)

NW $\quad$ NE $\quad$ SW $\quad$ SE $\quad$ TOTAL

\begin{tabular}{|c|c|c|c|c|c|}
\hline \multicolumn{6}{|l|}{$\begin{array}{l}\text { TWO-METER } \\
\text { COLLECTION }\end{array}$} \\
\hline flakes & 15.0 & 56.0 & 12.5 & 16.5 & $100 \%$ \\
\hline $\begin{array}{l}\text { total } \\
\text { cultural } \\
\text { material }\end{array}$ & 16.1 & 53.8 & 12.7 & 17.4 & $100 \%$ \\
\hline \multicolumn{6}{|l|}{$\begin{array}{l}\text { GENERAI } \\
\text { COLLECTION }\end{array}$} \\
\hline $\begin{array}{l}\text { worked \& } \\
\text { utilized } \\
\text { stone }\end{array}$ & 16.2 & 53.2 & 8.6 & 22.0 & $100 \%$ \\
\hline
\end{tabular}

TABLE 2

TOTALS OF FLAKES FROM TWO-METER COLLECTION SQUARES

$\begin{array}{lrrrrr} & \text { NW } & \text { NE } & \text { SW } & \text { SE } & \text { TOTAL } \\ \text { Interior flakes } & 26 & 97 & 15 & 21 & 159 \\ \text { Secondary flakes } & 5 & 23 & 10 & 8 & 46 \\ \text { Cortex flakes } & -- & 15 & 3 & 6 & 24 \\ \text { Utilized flakes } & 9 & 14 & 5 & 9 & 37 \\ \text { Misc. flint chips } & 11 & 21 & 6 & 11 & 49 \\ \text { Biface fragments } & -- & -- & 1 & -- & 1 \\ \end{array}$

TABLE 3

PERCENTAGES OF INTRA-QUADRANT FLAKE TYPES

$\begin{array}{lcccc} & \text { NW } & \text { NE } & \text { SW } & \text { SE } \\ \text { Cortex flakes* } & 0 & 11.1 & 10.7 & 17.1 \\ \text { Secondary flakes } & 16.1 & 17.0 & 35.7 & 22.8 \\ \text { Interior flakes } & 83.9 & 71.9 & 53.6 & 60.0\end{array}$

* Cortex flakes are defined as having $100 \%$ cortex on dorsal face. 
TABLE 4

LITHIC COLLECTION BY QUADRANT (INCLUDES MATERIALS FROM

TWO-METER COLLECTION SQUARES)

\begin{tabular}{lccccc} 
& NW & NE & SW & SE & TOTAL \\
$\begin{array}{l}\text { Projectile } \\
\text { points }\end{array}$ & 3 & 7 & 1 & 2 & 13 \\
$\begin{array}{l}\text { Thin bifaces } \\
\text { Thick bifaces }\end{array}$ & 9 & 15 & 6 & 9 & 39 \\
$\begin{array}{l}\text { Cores } \\
\begin{array}{l}\text { Retouched } \\
\text { flakes }\end{array}\end{array}$ & 2 & -- & 2 & 4 & 8 \\
$\begin{array}{l}\text { Utilized } \\
\text { flakes }\end{array}$ & - & 4 & -- & -- & 4 \\
& & 140 & 22 & 54 & 257 \\
\hline
\end{tabular}

TABLE 5

INTRA-QUADRANT DISTRIBUTION OF BIFACE TYPES (BY PERCENTAGE)

NW NE SW SE

\begin{tabular}{|c|c|c|c|c|}
\hline $\begin{array}{c}\text { Projectile } \\
\text { points }\end{array}$ & 20.0 & 23.2 & 12.5 & 11.8 \\
\hline \multicolumn{4}{|l|}{ Other thin } & 52.9 \\
\hline \multicolumn{5}{|l|}{ Total thin } \\
\hline bifaces & 80.0 & 73.3 & 87.5 & 64.7 \\
\hline Thick bifaces & 20.0 & 26.7 & 12.5 & 35.3 \\
\hline $\begin{array}{l}\text { Total (al1 } \\
\text { biface catego }\end{array}$ & 100.0 & 100.0 & 100.0 & 100.0 \\
\hline
\end{tabular}


TABLE 6

INTER-QUADRANT DISTRIBUTION OF BIFACE TYPES (BY PERCENTAGE)

\begin{tabular}{|c|c|c|c|c|c|}
\hline & NW & $\mathrm{NE}$ & SW & $\mathrm{SE}$ & TOTAI \\
\hline $\begin{array}{l}\text { Projectile } \\
\text { points }\end{array}$ & 23.0 & 53.9 & 7.7 & 15.4 & 100.0 \\
\hline $\begin{array}{c}\text { Other thin } \\
\text { bifaces }\end{array}$ & 23.1 & 38.5 & 15.4 & 23.0 & 100.0 \\
\hline Thick bifaces & 16.7 & 44.4 & 5.6 & 33.3 & 100.0 \\
\hline Total bifaces & 21.4 & 42.9 & 11.4 & 24.3 & 100.0 \\
\hline
\end{tabular}

TABLE 7

INTER-QUADRANT DISTRIBUTION OF BIFACES AND UTILIZED FLAKES (BY PERCENTAGE)

\begin{tabular}{lccccc} 
& NW & NE & SW & SE & TOTAL \\
Bifaces & 21.4 & 42.9 & 11.4 & 24.3 & 100.0 \\
Utilized flakes & 16.0 & 54.5 & 8.5 & 21.0 & 100.0 \\
Total lithics & 17.1 & 51.3 & 9.5 & 22.1 & 100.0 \\
\hline
\end{tabular}

TABLE 8

INTRA-QUADRANT DISTRIBUTION OF BIFACES AND UTILIZED FLAKES (BY PERCENTAGE)

$\begin{array}{lcccc} & \text { NW } & \text { NE } & \text { SW } & \text { SE } \\ \text { Bifaces } & 25.9 & 17.2 & 25.0 & 22.7 \\ \text { Utilized flakes } & 70.7 & 80.5 & 68.8 & 72.0 \\ \text { Total* } & 96.6 & 97.7 & 93.8 & 94.7\end{array}$

s.

*Excludes percentages of cores and trimmed flakes 
TABLE 9

MEAN WEIGHTS OF LITHIC DEBITAGE FROM TWO-METER COLLECTION SQUARES*

$\begin{array}{lcccc} & \mathrm{NW} & \mathrm{NE} & \mathrm{SW} & \mathrm{SE} \\ \text { Secondary flakes } & 6.5 & 1.0 & 4.2 & 1.1 \\ \text { Cortex flakes } & 0 & .7 & 2.3 & 3.0 \\ \text { Interior flakes } & .9 & .5 & 1.3 & 1.5 \\ \text { Chips and chunks } & 3.5 & 2.1 & 7.3 & 19.3 \\ \text { Utilized flakes } & 8.5 & 4.2 & 4.3 & 5.1\end{array}$

*Weights are in grams 